\title{
RANCANG BANGUN SISTEM INFORMASI GEOGRAFIS TEMPAT PARIWISATA DI PULAU TIMOR BERBASIS WEB
}

\author{
Karolina Yunita Solle ${ }^{1)}$, Natalia Magdalena R. Mamulak ${ }^{2)}$, Patrisius Batarius ${ }^{3)}$ \\ ${ }^{1,2,3}$ Ilmu Komputer, Fakultas Teknik, Universitas Katolik Widya Mandira Kupang \\ 1,2,3 J1. San Juan No.1-Penfui, Kupang, 85361 \\ E-mail : yunita.solle@gmail.com ${ }^{1)}$, mamulak.natalia@gmail.com ${ }^{2)}$, pbatarius@gmail.com ${ }^{3)}$
}

\begin{abstract}
ABSTRAK
Provinsi Nusa Tenggara Timur (NTT) merupakan salah satu dari 10 provinsi yang ditetapkan oleh Pemerintah menjadi destinasi unggulan wisata. Daya Tarik Wisata (DTW) yang dimiliki oleh Provinsi NTT sebanyak 458 DTW. Dengan meningkatnya jumlah wisatawan yang berkunjung ke NTT, Pulau Timor menjadi salah satu tempat tujuan utama wisatawan. Pulau Timor adalah sebuah pulau dibagian selatan Nusantara. Pulau ini dikenal memiliki jutaan pesona kekayaan alam, perairan yang jernih, hutan yang unik, serta kehidupan suku-suku Timor yang masih menjaga tradisi. Namun informasi dalam sebuah website dengan alamat www.dispar.nttprov.go.id, disampaikan cenderung dalam format yang statis dan relatif sulit untuk diperbarui infonya dengan cepat. Oleh karena itu, melalui Sistem Informasi Geografis Pariwisata diharapkan dapat menampilkan gambaran peta wisata pulau timor sehingga lebih menarik dan dapat dinikmati oleh masyarakat luas. Metode pengembangan sistem yang digunakan adalah metode Waterfall (Siklus Air Terjun). Tampilan peta menggunakan Google Maps API, bahasa pemrograman yaitu PHP7 dan MySQL sebagai database server. Sistem informasi geografis tempat pariwisata di pulau timor berbasis web ini merupakan sistem yang memberikan informasi kepada masyarakat mengenai lokasi objek wisata di pulau timor beserta fasilitas pendukungnya meliputi informasi lokasi tempat wisata, jenis wisata, berita dan fasilitas sekitar lokasi wisata.
\end{abstract}

\section{Kata Kunci: Sistem Informasi Geografis, Provinsi Nusa Tenggara Timur, Pulau Timor, Pariwisata}

\section{PENDAHULUAN}

Provinsi Nusa Tenggara Timur (NTT) merupakan salah satu provinsi kepulauan di Indonesia yang wilayahnya disatukan oleh laut Sawu dan Selat Sumba dengan jumlah Pulau kurang lebih 550 pulau, dengan 3 pulau utama yaitu Pulau Flores, Pulau Timor, dan Pulau Sumba. Memiliki luas daratan $\pm 47.349,9 \mathrm{Km}^{2}$ dan luas lautan $\pm 200.000 \mathrm{Km}^{2}$. Wilayah administratif terdiri dari 21 Kabupaten dan 1 Kotamadya, 306 Kecamatan dan 3270 Desa/Kelurahan. Dengan meningkatnya jumlah wisatawan yang berkunjung ke NTT, Pulau Timor menjadi salah satu tempat tujuan utama wisatawan. Pulau Timor adalah sebuah pulau dibagian selatan Nusantara, terletak di antara negara Timor Leste dan Kawasan Timor Barat. Luas Pulau ini sekitar 30.777 $\mathrm{km}^{2}$, terdapat 5 kabupaten dan 1 kota madya yakni, Kota Kupang, Kabupaten Kupang, Kabupaten TTS, Kabupaten TTU, Kabupaten Malaka dan Kabupaten Belu. Pulau ini memiliki potensi pariwisata yang kaya raya, dimana Pulau ini dikenal memiliki jutaan pesona kekayaan alam, perairan yang jernih, hutan yang unik, serta kehidupan suku-suku Timor yang masih menjaga tradisi.

Dinas Pariwisata Provinsi NTT merupakan instansi pemerintah yang mempunyai peranan penting dalam mengelola dan memberikan informasi perihal pariwisata dengan lebih cepat dan up to date. Namun informasi dalam sebuah website dengan alamat www.dispar.nttprov.go.id, disampaikan cenderung dalam format yang statis dan relatif sulit untuk diperbarui infonya dengan cepat. Dengan kendala promosi yang dihadapi dari Dinas Pariwisata Provinsi NTT, maka perlu dibangan sebuah sistem informasi geografis.

Dengan dibangunnya Sistem Informasi Geografis tempat wisata tentunya dapat membantu wisatawan yang akan berwisata di Pulau Timor untuk menentukan lokasi objek wisata yang ingin dikunjungi, fasilitas apa saja yang ada di lokasi wisata, serta rute yang harus dilalui untuk mencapai tempat wisata.

Penelitian mengenai sistem informasi geografis pariwisata pernah dilakukan sebelumnya oleh Swastikayana (2011), tentang "Sistem Informasi Geografis Berbasis Web Untuk Pemetaan Pariwisata Kabupaten Gianyar". Metodologi pengembangan sistem yang digunakan dalam penelitian ini adalah dengan metode Waterfall (Siklus Air Terjun). Penelitian ini memanfaatkan Google Maps API untuk Perancangan peta yang ditampilkan dalam web. Penelitian tersebut telah menghasilkan sebuah Sistem Informasi Geografis Berbasis Web yang dapat membantu Dinas Pariwisata Kabupaten Gianyar untuk menginformasikan wisata kepada masyarakat secara efektif dan efisien tetapi tidak menampilkan informasi jalur alternatif. 
Penelitian yang dilakukan oleh Regina, Natalia (2015) tentang "Sistem Informasi Geografis Pariwisata Kabupaten Timor Tengah Selatan (TTS)", penelitian ini memanfaatkan Google Maps API untuk mengetahui lokasi (latitude dan longitude), membuat peta online, dan kategori wisata jalur alternatif. Metode yang digunakan dalam penelitian ini adalah dengan metode Waterfall (Siklus Air Terjun). Penelitian ini di lakukan untuk memudahkan pengunjung untuk mengetahui lokasi objek wisata dan fasilitas yang ada di sekitar objek wisata tanpa mendatangi Dinas Pariwisata.

Penelitian yang akan dilakukan tentang "Perancangan Sistem Informasi Geografis Tempat Pariwisata di Pulau Timor Berbasis Web". Penelitian ini mengacu pada penelitian yang dilakukan oleh Swastikayana pada tahun 2011. Adapun persamaan dari kedua penelitian ini terletak pada metode yang digunakan yaitu metode Waterfall (Siklus Air Terjun). Penelitian tersebut telah menghasilkan sebuah Sistem Informasi Geografis Berbasis Web yang dapat membantu Dinas Pariwisata Kabupaten Gianyar untuk menginformasikan wisata kepada masyarakat secara efektif dan efisien tetapi tidak menampilkan informasi jalur atau rute lokasi. Kekurangan dari sistem tersebut, maka penulis merancang sebuah Sistem Informasi Geografis yang dapat menampilkan informasi visualisasi tempat, fasilitas wisata dan rute yang harus dilalui.

Oleh karena itu, pada perancangan Sistem Informasi Geografis Tempat Pariwisata di Pulau Timor Berbasis Web, penulis menggunakan metode Waterfall (Siklus Air Terjun), Google Maps API dan Bahasa pemrograman $P H P 7$, program yang belum digunakan pada penelitianpenelitian sebelumnya. Penelitian ini diharapkan dapat menjadi solusi alternatif bagi Dinas Pariwisata Provinsi NTT dalam mengoptimalkan sistem teknologi informasi di lingkungannya.

\section{RUANG LINGKUP}

Ruang lingkup dalam penelitian ini dibatasi dalam beberapa hal yang tertuang dalam cakupan permasalahan, batasan penelitian dan rencana hasil yang didapat. Berikut adalah penjabaran ruang lingkup dalam 3 poin utama, yaitu:

\section{Cakupan permasalahan}

Kurangnya media yang dapat memberikan informasi geografis tentang tempat-tempat wisata di Pulau Timor. Adapun pengelolaan Sistem informasi pada Dinas Pariwisata Provinsi NTT belum optimal dan media informasi yang ada belum cukup optimal dalam memudahkan wisatawan untuk mencari lokasi objek wisata di Pulau Timor.

2. Batasan-batasan penelitian

Konten wisata yang tersaji pada sistem ini terdiri dari wisata pantai, wisata alam, wisata budaya, wisata sejarah, wisata kuliner, wisata religi, kampung tradisional, festival budaya, wisata belanja, wisata buatan dan wisata diving, serta fasilitas umum seperti sarana penginapan, sarana rumah makan, sarana kesehatan, bank, ATM, dan berita yang ada di sekitar objek wisata untuk menunjang tujuan wisata. Sebagian data objek penelitian diambil pada Dinas Pariwisata Provinsi NTT.

3. Rencana hasil yang didapatkan

Merancang bangun Sistem Informasi Geografis tempat-tempat pariwisata di Pulau Timor. Membantu pengelolaan Sistem Informasi pariwisata pada Dinas Pariwisata Provinsi NTT serta membuat media informasi yang optimal untuk mempermudah wisatawan dalam mencari lokasi objek wisata di Pulau Timor.

\section{BAHAN DAN METODE}

Berikut disajikan bahan kajian dan metode yang dilakukan.

\subsection{Sistem Informasi Geografis}

Pada dasarnya, istilah sistem informasi geografis merupakan gabungan dari tiga unsur pokok: sistem, informasi, dan geografis. Dengan demikian, pengertian terhadap ketiga unsur-unsur pokok ini akan sangat membantu dalam memahami sistem informasi geografis. Dengan melihat unsur-unsur pokoknya, maka jelas sistem informasi geografis merupakan salah satu sistem informasi. Atau sistem informasi geografis merupakan suatu sistem yang menekankan pada unsur informasi geografis. Istilah "geografis" merupakan bagian dari spasial (keruangan). Kedua istilah ini sering digunakan secara bergantian atau tertukar hingga timbul istilah yang ketiga, geospasial. Ketiga istilah ini mengandung pengertian yang sama di dalam konteks sistem informasi geografis (SIG).

Penggunaan kata "geografis" mengandung pengertian suatu persoalan mengenai bumi: permukaan dua atau tiga dimensi. Istilah "informasi geografis" mengandung pengertian informasi mengenai tempattempat yang terletak di permukaan bumi, pengetahuan mengenai posisi dimana suatu objek terletak di permukaan bumi, dan informasi mengenai keteranganketerangan (atribut) yang terdapat di permukaan bumi yang posisinya diberikan atau diketahui. Maka SIG merupakan suatu kesatuan formal yang terdiri dari berbagai sumber daya fisik dan logika yang berkenaan dengan objek-objek yang terdapat di permukaan bumi (Prahasta, 2009).

Jadi SIG juga merupakan sejenis perangkat lunak yang dapat digunakan untuk pemasukan, penyimpanan, manipulasi, menampilkan, dan keluaran informasi geografis berikut atribut-atributnya. Menurut Demers definisi SIG adalah sistem komputer yang digunakan untuk mengumpulkan, memeriksa, mengintegrasikan, dan menganalisa informasi-informasi yang berhubungan dengan permukaan bumi (Prahasta, 2009).

\subsection{Metode Air Terjun}

Model air terjun (waterfall) adalah model satu arah Menurut Pressman (2010), model waterfall adalah model 
klasik yang bersifat sistematis, berurutan dalam membangun software. Nama model ini sebenarnya adalah "Linear Sequential Model". Model ini sering disebut dengan "classic life cycle" atau model waterfall.

1. Tahap Analisis

Pada tahap ini lebih fokus pada perencanaan, proses pengumpulan data berdasarkan kebutuhan pengguna sistem untuk menyelesaikan permasalahan. Adapun metode yang digunakan dalam pengumpulan data yaitu wawancara dan studi pustaka.
2. Tahap Desain

Merupakan tahap perancangan terhadap hasil yang didapat dari tahap analisis yang meliputi perancangan basis data, perancangan masukan dan keluaran serta perancangan interface. Ditampilkan dari gambar 1 sampai gambar 3 perancangan flowchart dan relasi diagram

1) Bagan alur sistem (systems flowchart)

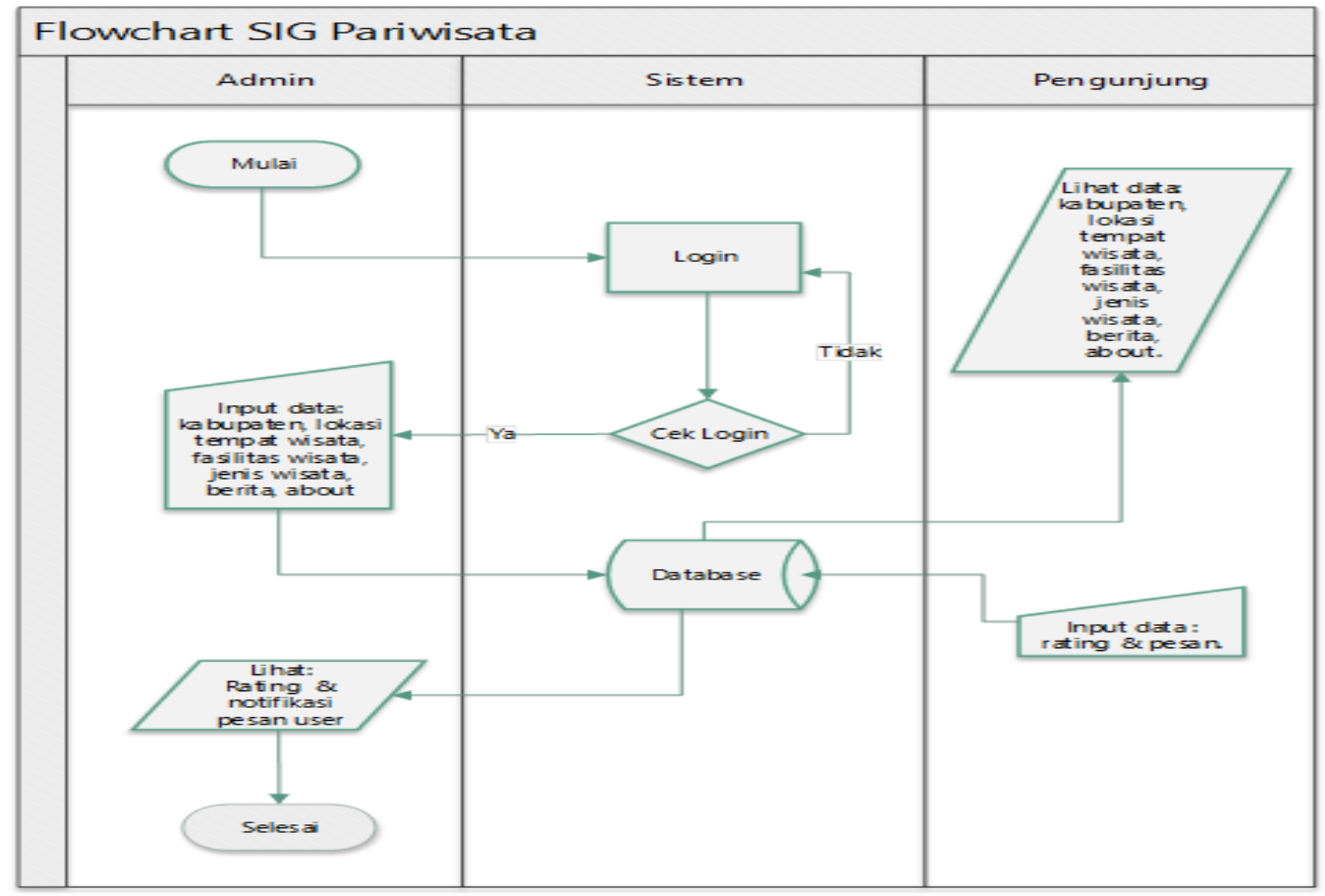

Gambar 1. Flowchart Sistem

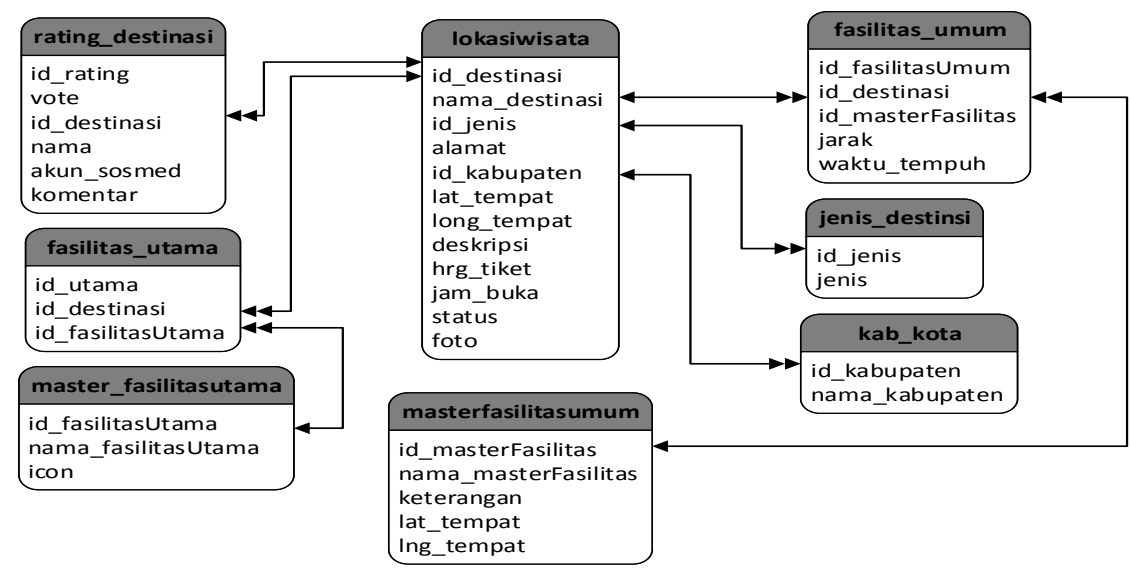

\begin{tabular}{|l|}
\hline \multicolumn{1}{|c|}{ berita } \\
\hline $\begin{array}{l}\text { id_berita } \\
\text { judul } \\
\text { kategori } \\
\text { isi } \\
\text { tanggal_post } \\
\text { gambar } \\
\text { post_by }\end{array}$ \\
\hline
\end{tabular}
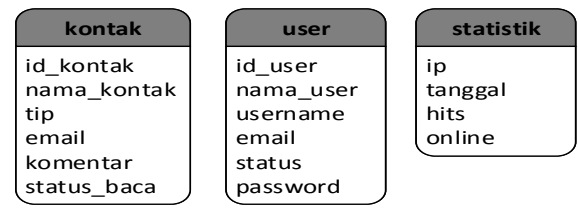

Gambar 2. Relasi antar tabel 
2) ER-Diagram
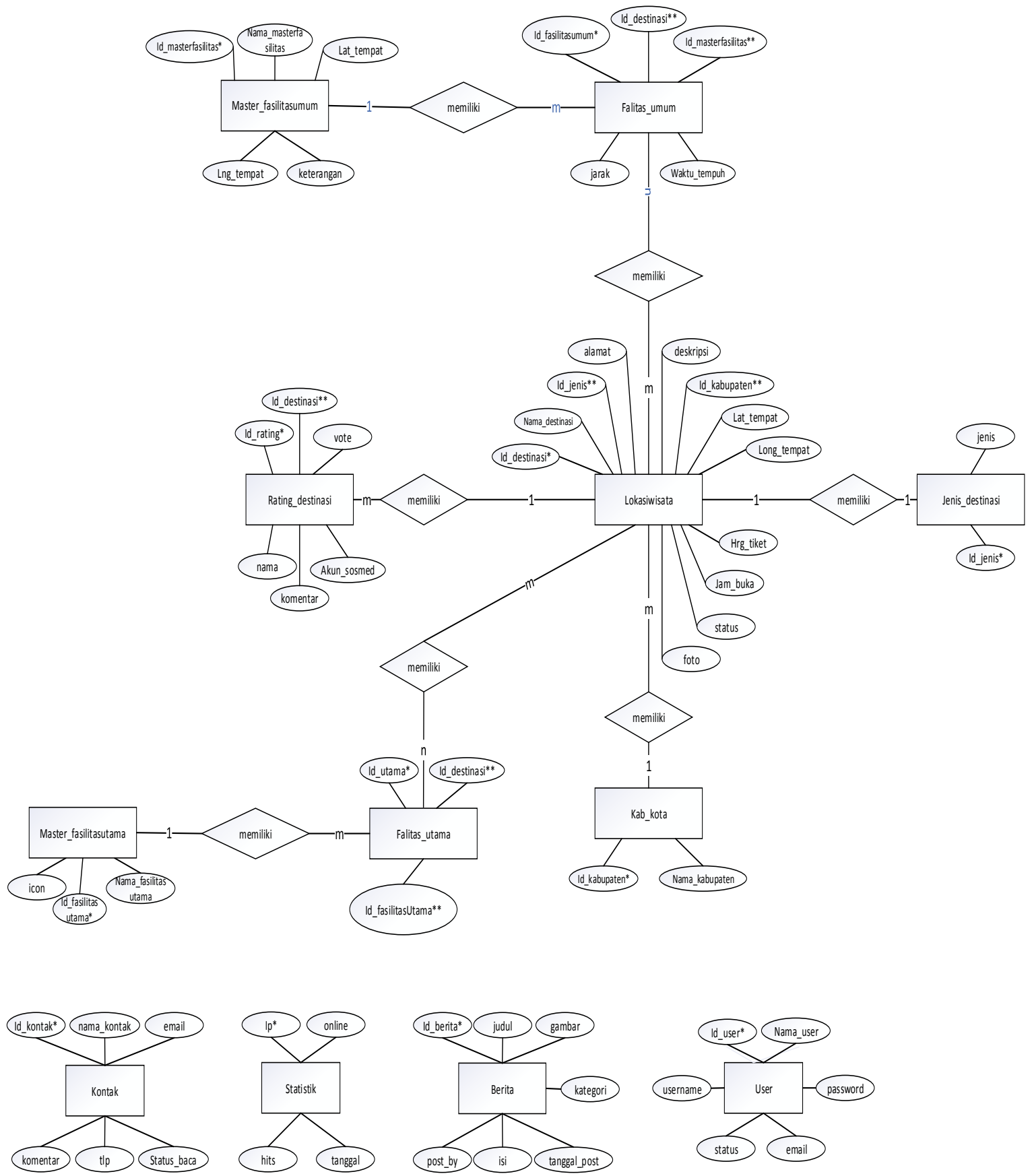

Gambar 2. ERD

3. Tahap Implementasi

Coding merupakan proses desain yang biasa dikenali oleh komputer. Dilakukan oleh seorang programmer yang akan menerjemahkan transai yang akan diminta oleh user, dengan kata lain penggunaan komputer akan dimaksimalkan dalam tahapan ini. Setelah pengkodean selesai akan dilakukan testing terhadap sistem yang telah dibuat. Program bantu dalam sistem ini akan dibangun menggunakan bahasa pemrograman PHP7 dengan memakai DBMS MySQL. 
4. Tahap Pengujian

Tujuan dari tahap ini adalah menemukan kesalahankesalahan pada sistem dan kemudian memperbaiki. Dalam proses analisis hasil pengolahan data digunakan metode pengujian black-box.

5. Tahap Pemeliharaan

Proses pemeliharaan pada software diperlukan, termasuk di dalamnya adalah pengembangan, karena software yang dibuat tidak selamanya seperti itu. Ketika dijalankan mungkin saja masih ada kesalahan yang tidak ditemukan sebelumnya, atau ada penambahan fitur-fitur yang belum ada pada software. Pengembangan diperlukan ketika adanya perubahan atau pergantian pada sistem operasi, atau perangkat lainnya.

\section{PEMBAHASAN}

Sistem Informasi Geografis Tempat Pariwisata Pulau Timor berbasis Web ini dibangun menggunakan bahasa pemrograman $P H P 7$, tampilan peta menggunakan Google Maps Api, dan dihubungkan dengan relation database management system MySQL. Tampilan dari Sistem yang telah dibangun adalah sebagai berikut:

\subsection{Tampilan Web SIG Pariwisata Pulau Timor}

Menu ini berfungsi untuk menampilkan halaman utama dari program, untuk dilihat oleh pengunjung maupun admin ketika membuka web ini. Tampilan ini berupa peta wisata secara keseluruhan dimana terdapat filter pencarian bagi pengunjung yang ingin melihat wisata di Pulau Timor. Berikut Tampilan home pada gambar 4.

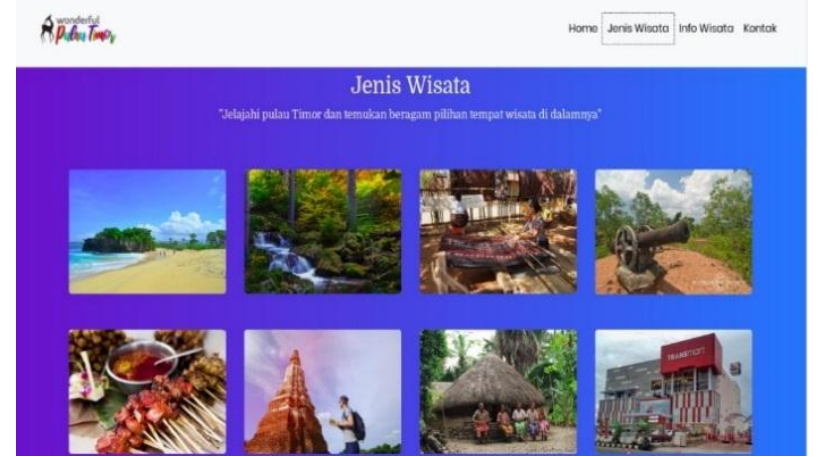

Gambar 4. Tampilan Halaman Home

Menu jenis wisata berfungi umtuk menampilkan 11 jenis wisata yang ada di Pulau Timor, dimana pengunjung dapat melihat jika disorot kedalam salah satu pilihan jenis. Tampilan ini dapat dilihat pada gambar 5 .
Nothow

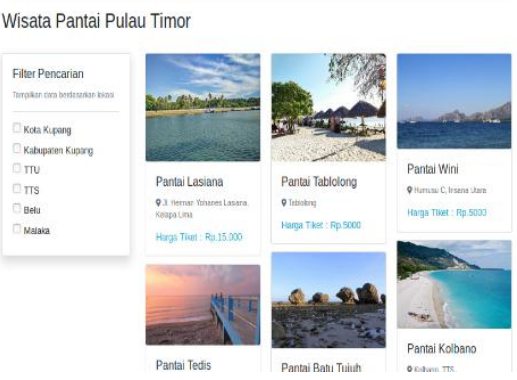

\section{Gambar 5. Tampilan Halaman Jenis Wisata}

Menu ini menampilkan list atau daftar tempat wisata pantai, harga tiket dan alamat tempat wisata yang ada di Pulau Timor. Berikut tampilannya pada gambar 6.

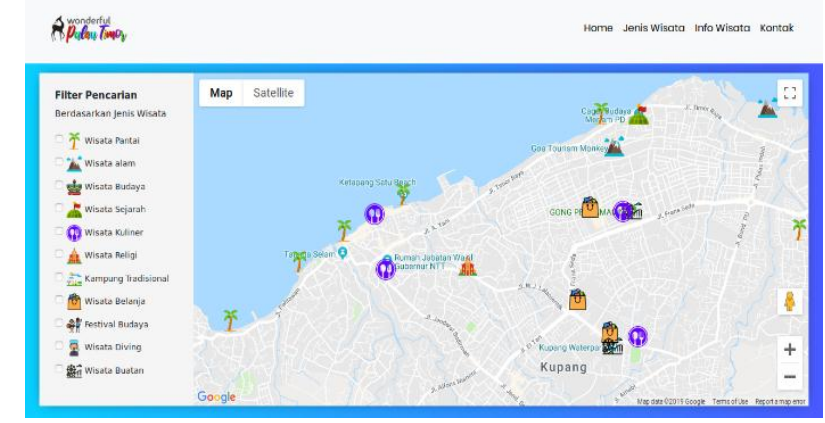

Gambar 6. Tampilan Halaman List Wisata

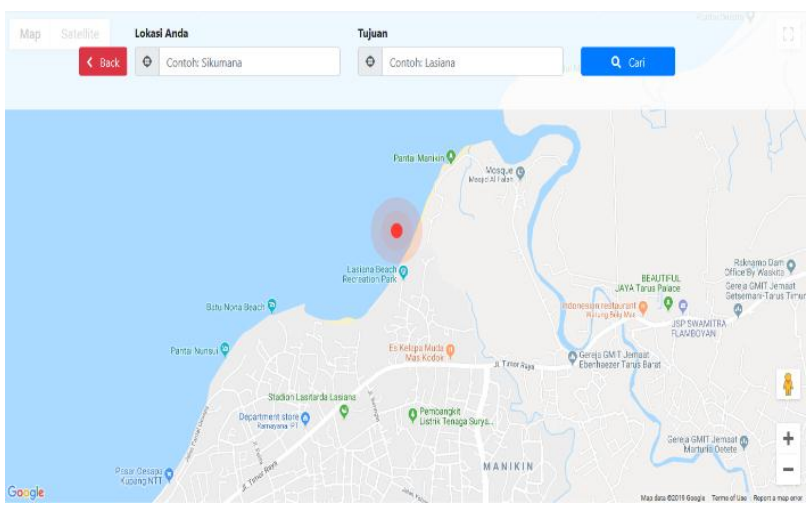

Gambar 7. Tampilan Halaman Rute Lokasi 


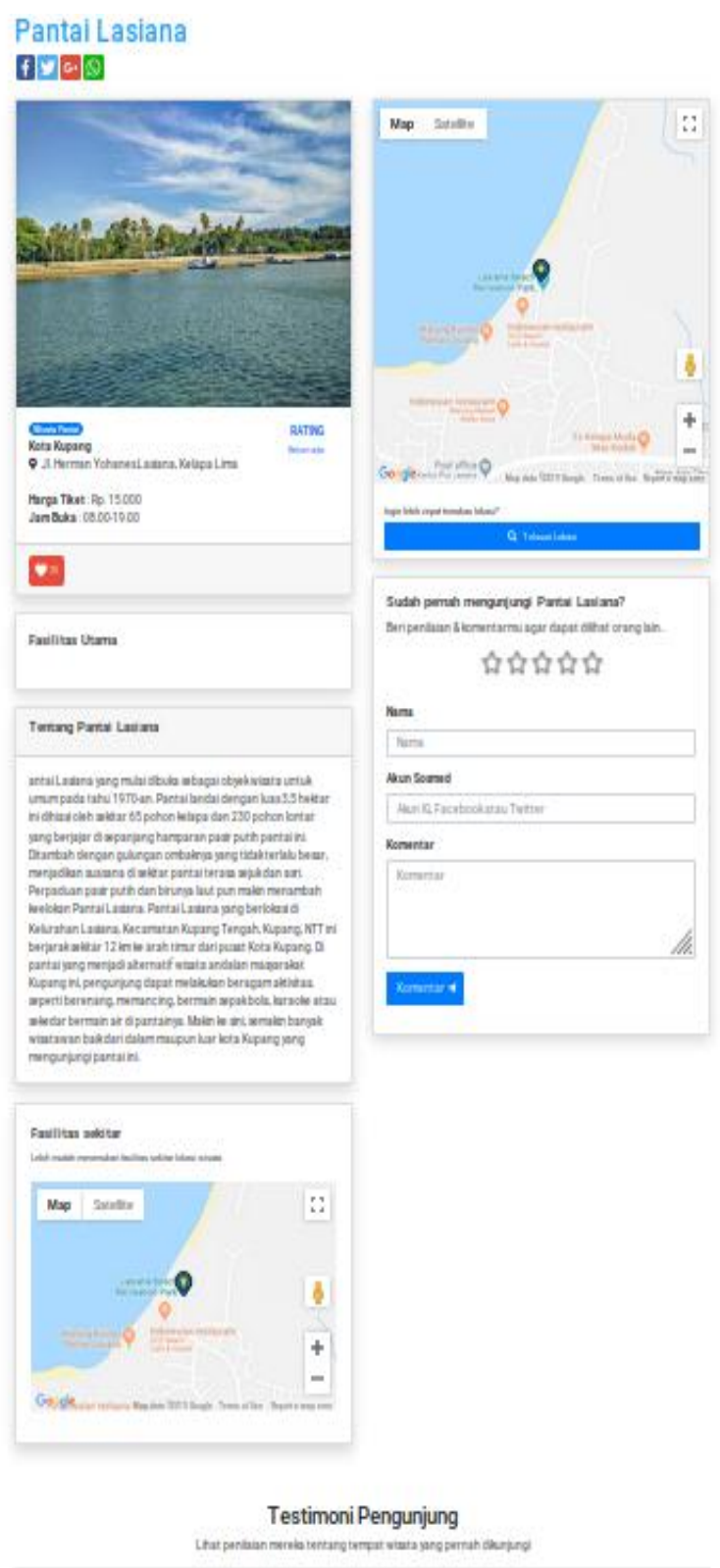

\section{Gambar 8. Tampilan Halaman Detail Wisata}

Menu ini digunakan pengunjung untuk mengetahui jalur yang harus ditempuh agar sampai kepada tujuan tempat wisata. Tampilan tersebut dapat dilihat pada gambar 7, sedangkan menu detail tempat wisata dimana terdapat foto tempat wisata, alamat harga tiket masuk, rating, fasilitas utama, deskripsi tempat wisata, fasilitas sekitar dan kolom komentar untuk pengunjung bisa berkomentar, terletak pada gambar 8 .

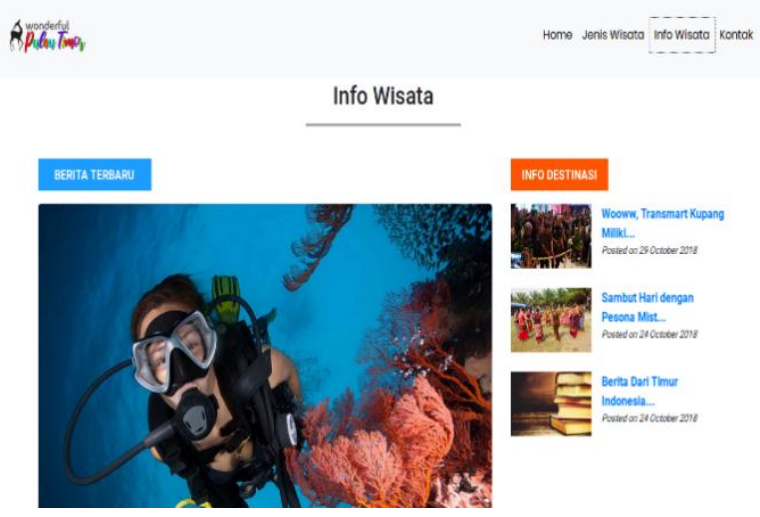

Gambar 9. Tampilan Halaman Info Wisata

Menu ini digunakan oleh pengunjung untuk melihat berita-berita wisata Pulau Timor. Terdapat 2 pilihan yaitu berita terbaru dan info destinasi. Tampilan ini dapat dilihat pada gambar 9. Sedangkan menu yang menampilkan rekomendasi-rekomendasi tempat wisata yang sering di kunjungi oleh wisatawan/pengunjung. Dengan tujuan untuk mempermudah pengunjung dalam menemukan wisata yang menarik dapat dilihat pada gambar 10.

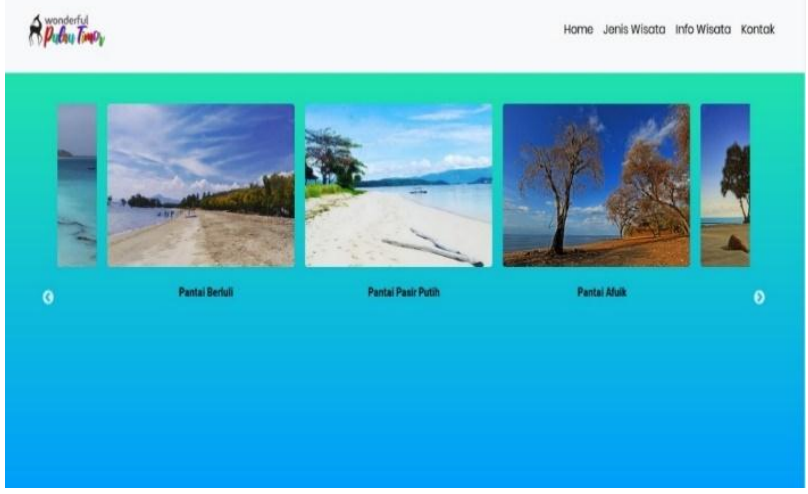

Gambar 10. Tampilan Halaman Rekomendasi Wisata

Menu ini digunakan oleh pengunjung untuk mengirim pesan kepada admin dengan tujuan sebagai masukkan atau saran tentang web ini.

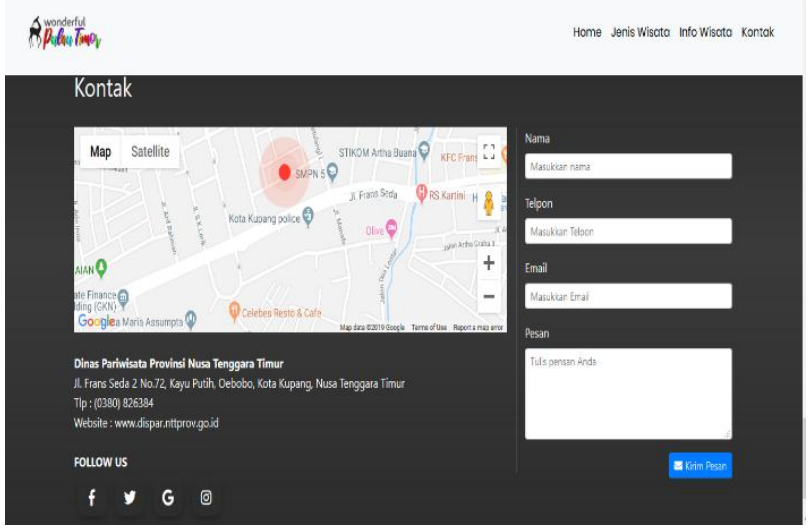

Gambar 11. Tampilan Halaman Kontak 


\subsection{Pengujian}

Metode pengujian yang digunakan dalam penelitian adalah black box testing. Pengujian black box berfokus pada persyaratan fungsional perangkat lunak. Dengan demikian pengujian black box memungkinkan perekayasa perangkat lunak mendapatkan serangkaian kondisi input yang sepenuhnya menggunakan semua persyaratan fungsional untuk semua program. Kebenaran perangkat lunak yang diuji hanya dilihat berdasarkan keluaran yang dihasilkan dari data atau kondisi masukkan yang diberikan untuk fungsi yang ada tanpa melihat bagaimnana proses untuk mendapatkan keluaran tersebut. Dari keluaran yang dihasilkan kemampuan program dalam memenuhi kebutuhan pemakai dapat diukur sekaligus dapat diketahui kesalahan kesalahannya.

Uji coba dengan black box pada sistem ini bertujuan untuk menentukan fungsi cara beroperasinya, apakah pemasukan data keluaran telah berjalan sebagaimana yang diharapkan. Langkah pengujian ini menggunakan dua kasus uji yaitu apabila sistem berjalan sesuai dengan harapan dan apabila terjadi kesalahan input.

Pengujian dengan menggunakan metode black box, adalah suatu pendekatan untuk dapat menguji dalam setiap fungsi di pada suatu program agar dapat berjalan dengan benar, tester dapat melihat beberapa proses yang dilakuan dalam pengujian ini diantaranya yaitu :

1. Fungsi-fungsi yang tidak benar, baik input atau pun output, dalam hal ini hanya melihat apakah proses input dan output sudah sesuai, contohnya jika ada software yang menampilkan form input data identitas, jika user melengkapi form maka program akan melakukan proses simpan, namun jika user tidak melengkapi form program tidak boleh melakukan proses simpan, jika perangkat lunak tidak sesuai misalnya tidak melengkapi form namun dapat tersimpan, hal ini perlu untuk diperbaiki.

2. Kesalahan interface, dalam hal kesalahan interface sering terjadi pada software yang tidak diuji coba dengan baik, misalnya tampilan web dengan menggunakan framework, ada beberapa framework yang tidak mendukung dengan beberapa browser, hingga tampilan interface kurang maksimal saat user memakai browser yang tidak mendukung framework yang digunakan.

3. Kesalahan dalam struktur data atau akses database, yang sering menjadi kendala, karena hal ini dapat berdampak pada akses web menjadi lamban, jika tidak diperhatikan.

4. Perilaku atau kinerja kesalahan yang ada pada perangkat lunak.

Inisialisasi dan penghentian kesalahan pada perangkat lunak

\section{KESIMPULAN}

Dengan dibangunnya sistem informasi geografis tempat pariwisata pulau timor berbasis web ini, membantu pengelolaan Sistem Informasi pariwisata pada Dinas pariwisata provinsi NTT dalam mempromosikan tempat wisata di pulau timor dan masyarakat dapat dengan mudah mencari lokasi tempat wisata di pulau timor. Lokasi tempat wisata terdata dengan baik sehingga masyarakat dapat memperoleh informasi pasti mengenai lokasi wisata yang menarik, fasilitas umum, dan fasilitas utama pada tempat wisata. Serta media informasi lebih optimal untuk mempermudah wisatawan dalam mencari lokasi objek wisata di Pulau Timor.

\section{SARAN}

Oleh karena keterbatasan kemampuan dan waktu dalam pembangunan sistem ini maka setelah melewati tahap pengujian atau testing maka dapat disarankan beberapa hal berikut ini: Sistem informasi geografis tempat pariwisata pulau timor berbasis web ini dibangun dengan tujuan untuk membantu masyarakat dalam mencari lokasi tempat wisata yang menarik dan dapat membantu Dinas Pariwisata dalam mempromosikan destinasi-testinasi ungulan di pulau timor. Penambahan fitur dapat dilakukan dengan bantuan admin untuk pengembang yang ingin mengembangkan aplikasi ini.

\section{DAFTAR PUSTAKA}

Arny Regina Fallo, Natalia Magdalena R. Mamulak, 2015, Sistem Informasi Geografis Pariwisata Kabupaten Timor Tengah Selatan (TTS), Universitas Katolik Widya Mandira Kupang-Nusa Tenggara Timur, Seminar Nasional Riset Inovatif III.

Elcom. 2010, Hebatnya Google Maps API dan Pintarnya Google Street, Yogyakarta: CV Andi Offset.

I Wayan Eka Swastikayana, 2011, Sistem Informasi Geografis Berbasis Web untuk Pemetaan Pariwisata Kabupaten Gianyar, Universitas Pembangunan Nasional "Veteran" Yogyakarta.

Pressman, Roger, 2010, Rekayasa Perangkat Lunak Pendekatan Praktisi (Buku Satu), Yogyakarta: Andi Offset.

Prahasta, Eddy, 2009, Sistem informasi geografis: konsep-konsep dasar. (edisi revisi). Bandung: informatika.

Ramadhana, C., W, Y. D., \& K.W, K. D. 2013. Data Mining dengan Algoritma Fuzzy C-Means Clustering Dalam Kasus Penjualan di PT Sepatu Bata. Seminar Nasional Teknologi Informasi \& Komunikasi Terapan 2013 (SEMANTIK 2013), ISBN: 979-26-0266-6.

Sumber: Data Buku Database Kepariwisataan Provinsi NTT Tahun 2016. 